\title{
Perceptions of Inclusion Education by Parents of Elementary School-Aged Children in Lampung, Indonesia
}

\section{Sofwan Adiputra}

Corresponding author. Sekolah Tinggi Keguruan dan Ilmu Pendidikan Muhammadiyah Pringsewu Lampung, Indonesia, sofwan@ konselor.org

Mujiyati

Sekolah Tinggi Keguruan dan Ilmu Pendidikan Muhammadiyah Pringsewu Lampung, Indonesia,muji2112@gmail.com

\section{Tri Yuni Hendrowati}

Sekolah Tinggi Keguruan dan Ilmu Pendidikan Muhammadiyah Pringsewu Lampung, Indonesia,yunisyajono@yahoo.co.id

Inclusive education requires the support of parents of children with disabilities and parents of normal children so that can be carried out well. However, there are often misunderstandings about parents about this. The purpose of this study is to be able to classify parents' perceptions about the application of inclusive education in schools. Researchers interviewed 177 respondents with parents' criteria from elementary school-age children (7-12 years) in six districts in Lampung. Furthermore, the results were analyzed based on educational and socioeconomic status (ESES). There are two groups of parents' perception responses, namely a group of parents who support and a group of parents who reject, which is then classified based on cognitive, behavioral, facility and social aspects. The perception of parents with low ESES was 30 parents with 25 agreed, and 4 refused. Parents' perceptions with moderate ESES, 41 parents with 10 agreed, and 7 refused. While the perception of parents with ESES was high, as many as 38 parents with, 18 agreed, and 4 refused. In general, ESES does not affect the perception of parents.

Keywords: inclusion education, perceptions, parents, elementary school, Indonesia

\section{INTRODUCTION}

The mixing of children with disabilities in public schools has become a major topic of debate among educational professionals (Avramidis, Bayliss, \& Burden, 2000). The consensus on the concept of inclusive education was agreed at the 48th session of the

Citation: Sofwan, A., Mujiyati, \& Hendrowati, T. Y. (2019). Perceptions of Inclusion Education by Parents of Elementary School-Aged Children in Lampung, Indonesia. International Journal of Instruction, 12(1), 199-212. https://doi.org/10.29333/iji.2019.12113a 
International Conference on Education in November 2008. The agreement recognizes that it is a continuing education process aimed at obtaining quality education for all, respecting the diversity, differences in needs, differences in abilities and characteristics of students. This concept seeks to eliminate all forms of discrimination in education (Blandul, 2010). In particular, inclusion as a means to increase participation in learning for all students so that their educational needs can be met (DePauw \& Doll-Tepper, 2000).

Inclusion is described as a process of reconstruction and change that encourages interaction, thus, inclusive education requires processes to improve communication and participation among students (Nilholm, 2006). In addition, social development in schools is very important as the implementation of inclusive education, because it must be able to make students be accepted within the school community (Dare, Nowicki, \& Felimban, 2017). This can be realized through healthy relationships among students that include participation in group activities, mutual feelings, and acceptance by classmates (Specht, 2013). In Western culture, inclusion can be understood as a social movement for equality and freedom (Fang, 2006).

The idea of incorporating students with disabilities into public education classes has become prevalent. However, this process is not at all easy, because not all children within the class are willing to recognize and accept differences as normality. Parents who have normal children often refuse to place their children in the same class as children with disabilities. In fact, parent participation in supporting inclusive education program is one of the most important aspects (Afolabi, Mukhopadhyay, \& Nenty, 2015; Tassoni, 2003). Family involvement is considered as an important factor associated with better outcomes in inclusive education. (Pérez Carreón, Drake, \& Barton, 2005). The results of research by $\mathrm{Xu} \&$ Filler, (2008) show that parental involvement is highly correlated to the success of children's education.

The active role of parents can be realized if the stakeholder can understand what the parent is concerned about in the child if inclusive education is applied. Therefore, research is needed on how parents' perceptions of inclusive education. This is because there is a feared misconception between parents' perceptions of inclusive education with the concept of inclusive education. Teachers and parents need intense communication in the implementation of inclusive education so that it can support its success (Reay, 2005). It is hoped that by understanding the wishes of parents, the government can develop programs aimed at building parents' trust in schools so that they can support the process of child development in schools (Lazarević \& Kopas-Vukašinović, 2013).

\section{LITERATURE REVIEW}

UNESCO (2005) explains that inclusive education as part to the program education for all, inclusion is seen as a process of addressing and responding to the diversity of learners' needs through increased participation in learning, culture, and society. It involves changes, modifications, approaches, structures, and strategies, with a vision that includes all children of the right age range and with the belief that educating children is the responsibility of all parties. 
This concept is not just about placing children with disabilities in general education settings but providing disabled children with equal opportunities to obtain a high-quality education, support, and services in the classroom. They are also placed in classes appropriate for their age and taught according to the needs of learners (Deng \& Zhu, 2007). As the practice of inclusive education is implemented, students with disabilities who attend school may receive the same education with their normal counterparts in the general-education class (Hunt \& McDonnell, 2007).

All countries are expected to be able to adopt inclusive education as a strategy to achieve education for all in accordance with the results of "The Salamanca Statement" agreed upon at The World Conference on Special Needs Education, in Salamanca, Spain (UNESCO, 1994). Inclusion is seen as an approach that can empower all people to participate and understand each other's differences and diversity ( $\mathrm{Yu}, \mathrm{Su}, \& \mathrm{Liu}$, 2011). The issue of inclusive education in various countries has made national and global policies increasingly focused on it (Armstrong, 1998). This overall trend is also substantially accelerated due to international commitments to inclusive education (Qi \& Ha, 2012).

The definition of inclusive education is progressive and constantly changing. It is necessary to clarify the concepts contained therein since many consider inclusive education to be another version of special education. Inclusion education is understood as an education service system that involves disabled children and normal children to study together in schools closest to where they live. The implementation of inclusive education requires the school to make adjustments both in terms of curriculum, facilities, and infrastructure, as well as learning systems tailored to the needs of individual learners (Direktorat Pembinaan Sekolah Luar Biasa, 2004).

Special facilities are also needed in the inclusive education to facilitate teachers in implementing teaching (Ring \& Travers, 2005). Inclusive education requires specificity in teaching materials, teaching techniques, equipment, and facilities so that there needs to be good preparation before the system is implemented (Zigmond, Kloo, \& Volonino, 2009).

It takes training of teachers who will become classroom teachers in inclusive education. Teacher professionalism and personal attitudes towards inclusion affect the application of inclusive education so that in need of teachers who have professional skills and a good personality in the field of inclusion (Starczewska, Hodkinson, \& Adams, 2012).

\section{METHOD}

\section{Study design and location}

We conduct qualitative research in 13 districts in Lampung, which have mixed ethnic group characteristics, to explore the situation in Indonesia (Badan Pusat Statistik Provinsi Lampung, 2014). We used the case study approach in our analysis (Yin, 1994). All transcripts were analyzed using NVivo Version 11 (Bazeley \& Jackson, 2013).

Each district in each city/district is numbered, and we select the region based on the last digit of the random number table. We selected six districts with different scores on the 
Human Development Index (high, medium and low); it is used as a measure of levels of educational and socioeconomic status (ESES). The selected samples in Way Kanan and West Lampung represent low ESES, Selected samples at Pesawaran and Tanggamus represents Medium ESES, and Sample selected in Pringsewu and Central Lampung represents a high ESES proportion. The rationale for selecting areas of different ESES is to gain a diversity of parental views on the implementation of inclusive education and to observe whether ESES is a factor that contributes to parents' perceptions.

\section{Respondents and recruitment process}

Interviews were conducted in six districts. Two studies were conducted in districts with low ESES, two in districts with medium ESES, and two in districts with high ESES (Badan Pusat Statistik Provinsi Lampung, 2014). Respondents who were selected were based on the same characteristics, namely parents of primary school-age children (7-12 years). Inclusion criteria were careers of children normal who hold or share the primary role in decision-making for the care of the child or were responsible, in children's education.

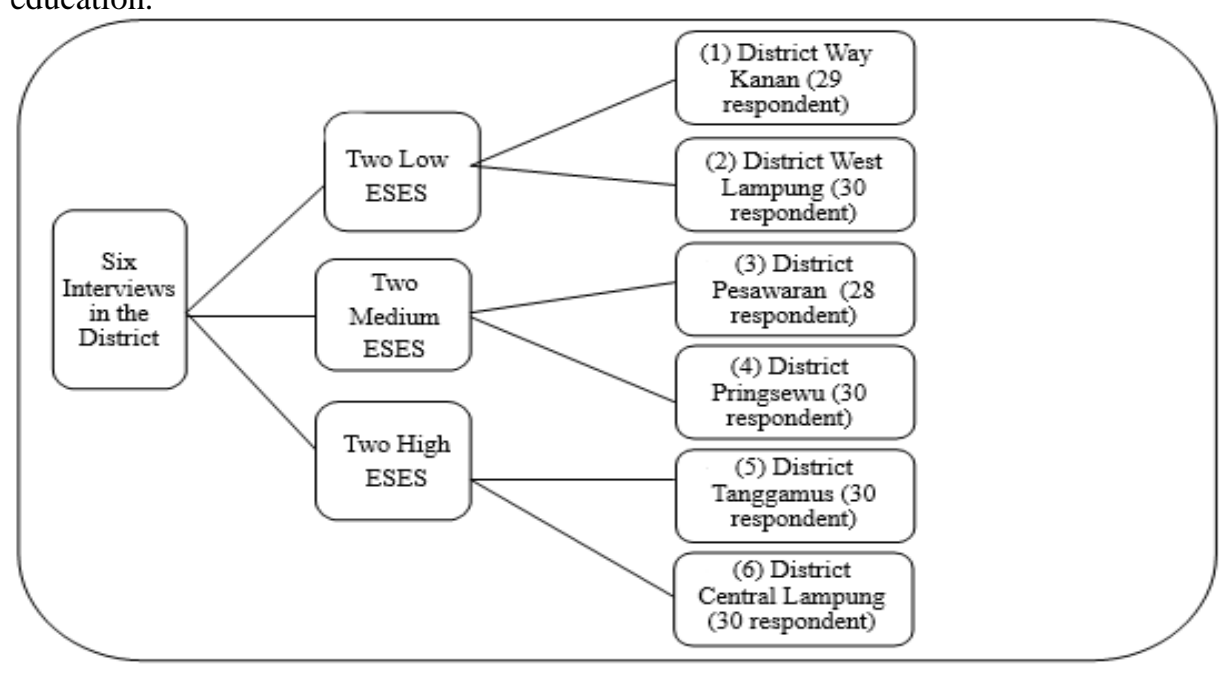

Figure1

Numbers and respondents of interview in Lampung, Indonesia. ESES: Education and socioeconomic status.

To recruit respondents from low and intermediate ESES areas, we asked for assistance from class coordinators in public elementary schools (a mother from each grade in elementary school who acts as the information source for fellow mothers). We also placed project information, including contact details in students' communication books (a book that teachers use to communicate with mothers of individual children). We collaborated with local teachers. We provided a verbal explanation of the project and disseminated the respondent's information statement to invite participation. 
Table 1

Questions used in Interview in Lampung Area, Indonesia

\begin{tabular}{llccc}
\hline English & Indonesian & Lampung Dialect A & Lampung Dialect O & Javanese \\
\hline 1. Currently, the & 1. Saat ini, pemerintah & 1.Tanno pemerintah lagi & 1.Tano ijo, pemerintah & 1.Saiki, pemerintah \\
government is & sedang & ngembangko & lagi ngembangko & esek ngembangke \\
developing an & mengembangkan & sistem pendidikan & sistem pendidikan & sistem pendidikan \\
inclusive education & sistem pendidikan & inklusi yakdo & inklusi yolah & sing jenenge \\
system that is & inklusi yaitu & pendidikan sai & pendidikan sai & inklusi yaiku \\
education that & pendidikan yang & nutukko sanak & nutuk sertako & pendidikan sing \\
includes children & mengikut sertakan & berkebutuhan & sanak sai & meluke anak \\
with special needs to & anak berkebutuhan & khusus nyin & kepentingan & berkebutuhan \\
learn together with & khusus untuk belajar & belajakh bakhong & khusus guwai & khusus ngo sinau \\
normal children in & bersama dengan anak & guk sanak normal & belajar bebarengan & bareng karo anak \\
schools adjacent to & normal di sekolah & di sekula sai & jamo sanak normal & normal neng \\
where they live. & yang berdekatan & sekhedik an guk & di sekulah sai & sekolah sing \\
What do you think & dengan tempat & lambanni. Khepa & sepaghekan jamo & cedak umah. Nek \\
about that? & tinggalnya. & pendapat & nuwo no. Nyo & menurute \\
2. Do you agree to & Bagaimana pendapat & bapak/ibu guk hal & pendapat sekam & bapak/ibu piye? \\
the government & bapak/ibu tentang hal & hinno? & tentang hal trsebut?2.Setuju ora bapak/ibu \\
program? Explain & tersebut? & 2.Setuju kodo bapak/ibu & 2.Setujew degh sekam & karo program \\
why? & 2. Setujukah bapak/ibu & tentang program & tentang program & pemerintah iku? \\
& tentang program & pemerintah hinno? & pemerintah & Alesane opo? \\
& pemerintah tersebut? & Keni alasanni? & tersebut? Juk ko & \\
& Berikan alasannya? & & alasanno? & \\
\hline
\end{tabular}

The research team, data collection, and approach to analysis

The field research team consisted of the first author (SAP), Second author (MJ) and six research assistants (FDM, DN, RN, JM, AN, DI). They underwent a three-day training program in qualitative research, concentrating on an interview, in Center for Research and Community Service STKIP Muhammadiyah Pringsewu Lampung. This process included a discussion of potential issues and problem-solving that might be encountered during the Interview.

The question guide was developed in Indonesian and finalized during the training with an unstructured interview format. Afterward, the guidelines were translated into the Lampung and Javanese languages, and a pilot interview was conducted to test the question's guidelines (Table 1). Javanese was also used in this study because it was the most widely used local language outside Lampung. Interview guidelines were written to facilitate interviewers if they found respondents who were less able to use Indonesian.

Table 2

Interviewer and Observer

\begin{tabular}{llll}
\hline District & SES & Interviewer & Observer \\
\hline Way Kanan & Low & FDM & SAP \\
West Lampung & Low & DN & SAP \\
Pesawaran & Medium & RN & SPA \\
Tanggamus & Medium & JM & MJ \\
Pringsewu & High & AN & MJ \\
Central Lampung & High & DI & MJ \\
\hline
\end{tabular}

All research assistants become an interviewer in the District (Table 2). SAP and MJ were observing and managing the recordings and timekeeping. Prior to each interview, the study team explained the Interviewer process to the respondents and asked them to 
fill in the basic demographic information form and provide written informed consent. Respondents were offered the language of their choice to be used during the Interview, either in Indonesian, Lampung, or Javanese. Interviews were conducted in a relay to all the people interviewed. We highlighted how much everyone's opinion was valued and encouraged the respondents to speak freely and to ensure confidentiality. To ensure consistency of the discussion, the interviewer used the same guideline, including a set of prompt questions. All interview processes took around 7 to 10 minutes per person.

Transcription and translation started immediately after all the interviews were done. Transcription was only done in Indonesian by MJ and checked by SAP to confirm that the transcript was in accordance with the recording. The research assistants then provided a reflection of the transcripts.

The research assistants were not involved in the analysis phase. The analysis was conducted following the steps: 1) SAP and MJ read all transcripts several times to ensure data. 2) SAP performed coding, comparing encoding within and between transcripts. 3) SAP and MJ identified classifications. 4) Once the final version of classifications was agreed upon, a combination of subclassification took place. 5) SAP and MJ identified similarities and differences between and within the different ESES groups. 6) The quotations that best represented each classification were identified. 7) All authors (SAP, MJ, and TYH) agreed upon the final version of the classifications.

\section{Credibility and trustworthiness}

Credibility and trustworthiness were addressed in several ways. SAP and MJ were the observer of all 177 interviewers. Therefore, description of the situation, opinions (words), the intonation of voice or facial expressions could be witnessed consistently. We reduced interpretive bias by involving another analyst (TYH) who was not present during the data collection. SAP and MJ also conducted triangulation with the one research assistant and used the notes made during the interviews to ensure the nuances captured during the discussion.

\section{FINDINGS}

\section{Characteristics of respondents}

Most caregivers from low ESES groups have graduated from elementary or secondary school and above, but none come from universities. Conversely, most caregivers of high ESES groups are university graduates. We have more maternal respondents compared to fathers in all three ESES groups (Table 3). We have parents from eight different ethnics. However, we do not find that ethnicity has a role in the interview.

There are two groups of parents' perception response, namely a group of parents who support inclusive education and a group of parents who reject inclusive education. The perception of parents with low ESES was 30 (50.84\%) parents with $25(42.37 \%)$ agreed, and $4(6.77 \%)$ refused. Parents' perceptions with moderate ESES, $41(70.68 \%)$ parents with $10(17.24 \%)$ agreed, and $7(12.06 \%)$ refused. While the perception of parents with ESES was high, as many as $38(63.33 \%)$ parents with, $18(30 \%)$ agreed, and $4(6.67 \%)$ refused. 
Table 3

Characteristics of respondents from interviewees in Lampung, Indonesia

\begin{tabular}{llll}
\hline & Low ESES (1,2) & Medium ESES $(3,4)$ & High ESES $(5,6)$ \\
\hline Total of parcipant & 59 & 58 & 60 \\
Mather & $50(84,7 \%)$ & $49(84.4 \%)$ & $50(83.3 \%)$ \\
Father & $9(15.3 \%)$ & $9(15.6 \%)$ & $10(16.7 \%)$ \\
Education & & & \\
Elementary or less & $20(33.8 \%)$ & $4(6.9 \%)$ & 0 \\
Middle \& High School & $39(66,2 \%)$ & $40(69 \%)$ & $32(53.4 \%)$ \\
University or higher & 0 & $14(24.1 \%)$ & $28(46.6 \%)$ \\
Ethnicities & Lampung, Jawa, & Lampung, Jawa, & Lampung, Jawa, Sunda, \\
& Sunda, Semendo & Palembang, komering & Palembang, Batak, Padang \\
\hline
\end{tabular}

\section{Emerging Responds}

Some parents responded to inclusive education. The relevant citations from the transcripts are presented in Table 4. Overall there was no difference in response from the three SES groups involved. Although we estimated that the differences would appear, but the overall response that parents provided was in common.

Table 4

Quotes on respond of inclusion education in Lampung, Indonesia

\begin{tabular}{|c|c|c|c|}
\hline & Low ESES $(1,2)$ & Medium SES $(3,4)$ & High SES $(5,6)$ \\
\hline $\begin{array}{l}\text { Discrimination } \\
\text { on the } \\
\text { perception of } \\
\text { education }\end{array}$ & $\begin{array}{l}\text { R1: Disagree with inclusive education } \\
\text { because disabled students cannot socialize } \\
\text { well. } \\
\text { R2: Disabled children are unsuitable for } \\
\text { studying in regular schools. } \\
\text { R3: Disagree, because disabled children } \\
\text { should get different teaching with normal } \\
\text { students. } \\
\text { R4: Do not agree, because children of } \\
\text { special needs will be left behind his } \\
\text { learning ability compared to normal } \\
\text { children. } \\
\text { R5: The capabilities they have will be } \\
\text { different. } \\
\text { R8: Children with disabilities should be } \\
\text { enrolled in a special school. }\end{array}$ & $\begin{array}{l}\text { R1: Because the disabled child } \\
\text { will be bullied and will make } \\
\text { them difficult to develop. } \\
\text { R2: Education for disabled } \\
\text { children is an extraordinary } \\
\text { school. } \\
\text { R3: In the learning, process } \\
\text { will occur imbalance. }\end{array}$ & $\begin{array}{l}\text { R1: Fear of normal children will } \\
\text { also experience disability. } \\
\text { R2: Disabled children and } \\
\text { normal children are only } \\
\text { combined occasionally. } \\
\text { R3: Children with disabilities } \\
\text { need special learning sites, } \\
\text { special learning methods, and } \\
\text { special teachers. } \\
\text { R4: Disabled children should be } \\
\text { schooled in extraordinary } \\
\text { schools. } \\
\text { R5: Children with disabilities are } \\
\text { difficult to follow normal child } \\
\text { development. }\end{array}$ \\
\hline $\begin{array}{l}\text { Children have } \\
\text { the right to } \\
\text { education }\end{array}$ & $\begin{array}{l}\text { R1: Children with disabilities also have the } \\
\text { same rights as normal children to learn. } \\
\text { R2: Inclusive education is an education } \\
\text { system that does not discriminate against } \\
\text { students. } \\
\text { R3: Equalize for students in education. } \\
\text { R4: All children have the right to education. }\end{array}$ & $\begin{array}{l}\mathrm{R} 1 \text { : Children with disabilities } \\
\text { have the right to develop their } \\
\text { self-awareness. } \\
\text { R2: Disabled children have the } \\
\text { right to obtain quality } \\
\text { education. }\end{array}$ & $\begin{array}{l}\text { R1: Every citizen of Indonesia } \\
\text { has the same right to obtain } \\
\text { education. } \\
\text { R2: Even though they have } \\
\text { shortcomings but have the same } \\
\text { potential as normal children. } \\
\text { R3: All students have equal } \\
\text { rights to attend lessons } \\
\text { regardless of disability. } \\
\text { R4: Children with disabilities } \\
\text { must remain in school. }\end{array}$ \\
\hline $\begin{array}{l}\text { Parents do not } \\
\text { understand the } \\
\text { inclusive } \\
\text { education }\end{array}$ & $\begin{array}{l}\text { R1: Inclusive education can reduce } \\
\text { children's play time. } \\
\text { R2: There is no inclusive education in our } \\
\text { area. } \\
\text { R3: Inclusive education supports our } \\
\text { economy. } \\
\text { R4: Inclusive education can improve the } \\
\text { ability of children to be more active }\end{array}$ & $\begin{array}{l}\text { R1: Helping children become } \\
\text { smarter. }\end{array}$ & $\begin{array}{l}\text { R1: Inclusive education can } \\
\text { improve intelligence in children. } \\
\text { R2: Inclusive education can } \\
\text { develop children's talents. }\end{array}$ \\
\hline
\end{tabular}




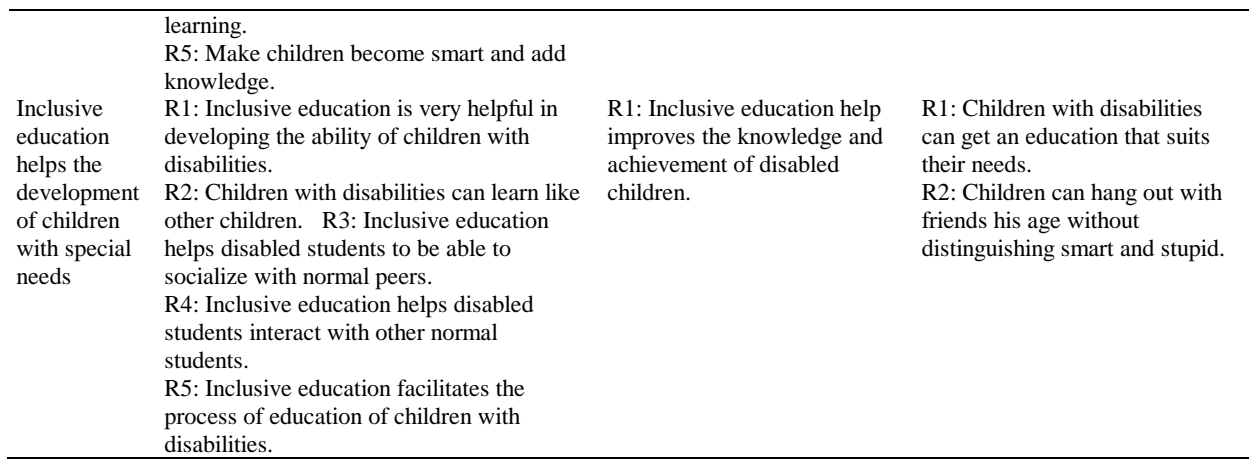

Discrimination on the perception of education

There are parents who have fears when their children go to school with children with disabilities. Some say that disabled children need special schools that cannot be mixed with normal children. This is because children with disabilities will find it difficult, to adapt to normal children's lessons because their capabilities are different and they will be bullied by normal children.

\section{Children have the right to education}

There are also several responses that support the implementation of inclusive education. They responded positively by stating that every child has the same right to education. In addition, many parents respond that, although disabled children have abnormalities, they have the potential to be equivalent to normal children, and every citizen has the right to access equal education.

\section{Parents do not understand the inclusive education}

There are parents who do not understand the essence of the implementation of inclusive education, especially in the low ESES group. Parents assume with inclusive education that the child will have more hours of lessons so reduce the time to play. Anyone who responds to inclusive education can help solve the problem of tuition fees.

Inclusive education helps the development of children with special needs

Inclusive education will improve the cognitive, affective and psychomotor development of student's disability. Besides that, it also improves students' normal social skills in helping students with disabilities. In addition, inclusive education simplifies the existing pattern of education as all children enter at the same school.

\section{Classification of perception}

There are two groups of parents' perceptions, namely a group of parents who support inclusive education and a group of parents who reject inclusive education. Both groups are divided into four classifications, namely cognitive, behavioral, facility and social (Table 5). 
Table 5

Quotes on classification of perception by parents of elementary school-aged children about inclusion education in Lampung, Indonesia

\begin{tabular}{|c|c|c|c|}
\hline & Low ESES $(1,2)$ & Medium ESES $(3,4)$ & High ESES $(5,6)$ \\
\hline \multicolumn{4}{|l|}{ Support } \\
\hline Cognitif & $\begin{array}{l}\text { R1: Inclusive education is helpful in } \\
\text { developing child talent. } \\
\text { R2: Helping students get the lessons } \\
\text { as needed. R3: Inclusive education } \\
\text { can foster students' abilities. } \\
\text { R4: Inclusive education can make } \\
\text { children more easily absorb lessons. }\end{array}$ & $\begin{array}{l}\text { R1: Inclusive education can improve } \\
\text { the creativity of children with } \\
\text { disabilities. } \\
\text { R2: Inclusive education can increase } \\
\text { knowledge and insight so that } \\
\text { children become smart. } \\
\text { R3: Inclusive education can add } \\
\text { knowledge and insight so that } \\
\text { children become smart and intelligent. } \\
\text { R4: Children with disabilities get an } \\
\text { education that suits their needs. }\end{array}$ & $\begin{array}{l}\text { R1: Children with disabilities can } \\
\text { have the same abilities as normal } \\
\text { children. } \\
\text { R2: Inclusive education can } \\
\text { improve and develop a mindset. } \\
\text { R3: Inclusive education can } \\
\text { develop talent. }\end{array}$ \\
\hline Behavioral & $\begin{array}{l}\text { R1: Disabled students can interact } \\
\text { with other normal students and get } \\
\text { help and support. } \\
\text { R2: Disabled child can learn to his } \\
\text { or her peers. } \\
\text { R3: Inclusive education can add to } \\
\text { the experience of students who are } \\
\text { disabled. }\end{array}$ & $\begin{array}{l}\text { R1: Children with disabilities do not } \\
\text { feel different from other children. } \\
\text { R2: Disability children can go to } \\
\text { school with normal children in the } \\
\text { same environment. } \\
\text { R3: Children can learn together } \\
\text { regardless of their differences and } \\
\text { shortcomings. }\end{array}$ & $\begin{array}{l}\text { R1: It is expected of students with } \\
\text { disabilities, and normal students } \\
\text { can share, also expected to learn } \\
\text { mutual respect, respect, love. } \\
\text { R2: Normal children can respect } \\
\text { each other with children with } \\
\text { disabilities. } \\
\text { R3: Children with disabilities can } \\
\text { slowly behave similarly to their } \\
\text { peers. } \\
\text { R4: Children with disabilities can } \\
\text { participate in learning with } \\
\text { children his age. }\end{array}$ \\
\hline Facilities & $\begin{array}{l}\text { R1: Inclusive education can help } \\
\text { parents who have a low economy to } \\
\text { send their disabled children to } \\
\text { school. }\end{array}$ & $\begin{array}{l}\text { R1: Disabled children can go to } \\
\text { school in their home environment. } \\
\text { R2: Make it easier for parents who } \\
\text { have children with disabilities to send } \\
\text { their children to school. }\end{array}$ & \\
\hline Social & $\begin{array}{l}\text { R1: Children who have a disorder } \\
\text { can communicate and socialize well } \\
\text { with peers. } \\
\text { R2: It helps disabled students to } \\
\text { interact with their peers. } \\
\text { R3: It can generate self-esteem, and } \\
\text { make them not isolated. }\end{array}$ & $\begin{array}{l}\text { R1: Children with disabilities can } \\
\text { socialize with their peers. } \\
\text { R2: Associating with one another can } \\
\text { increase the confidence of children } \\
\text { with disabilities to express feelings to } \\
\text { others. }\end{array}$ & $\begin{array}{l}\text { R1: Children can hang out with } \\
\text { friends his age without } \\
\text { distinguishing smart and stupid. } \\
\text { R2: Children with disabilities need } \\
\text { friends not to be excommu- } \\
\text { nicated. }\end{array}$ \\
\hline \multicolumn{4}{|c|}{ 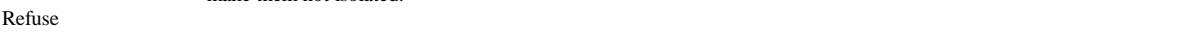 } \\
\hline Cognitif & $\begin{array}{l}\text { R1: Children with disabilities cannot } \\
\text { grasp the lesson well. } \\
\text { R2: Children with disabilities don't } \\
\text { respond quickly to lessons like } \\
\text { normal children. } \\
\text { R3: Children with disabilities should } \\
\text { get more special teaching than } \\
\text { normal students. } \\
\text { R4: The unequal ability can hamper } \\
\text { the learning process. }\end{array}$ & $\begin{array}{l}\text { R1: Have different curriculum targets, } \\
\text { because of different abilities. }\end{array}$ & $\begin{array}{l}\text { R1: Children with disabilities if } \\
\text { attending public school will make } \\
\text { them burdened. } \\
\text { R2: Normal learning activities are } \\
\text { very dense. }\end{array}$ \\
\hline Behavioral & $\begin{array}{l}\text { R1: Public schools cannot maximize } \\
\text { disabled students' abilities. } \\
\text { R2: Children with disabilities should } \\
\text { get more special teaching than } \\
\text { normal students. }\end{array}$ & $\begin{array}{l}\text { R1: Children with disabilities will be } \\
\text { bullied and ostracized. } \\
\text { R2: Children with disabilities will be } \\
\text { mocked by friends. }\end{array}$ & $\begin{array}{l}\text { R1: Disrupt the learning process in } \\
\text { regular schools because their } \\
\text { curriculum is different. } \\
\text { R2: Children with disabilities need } \\
\text { specialization in learning, while } \\
\text { not all schools have it. }\end{array}$ \\
\hline Facilities & $\begin{array}{l}\text { R1: Teachers cannot serve students } \\
\text { with special needs personally. } \\
\text { R2: Disabled children should study } \\
\text { at an extraordinary school. }\end{array}$ & $\begin{array}{l}\text { R1: The education needed by disabled } \\
\text { children is an exceptional school. }\end{array}$ & $\begin{array}{l}\text { R1: Children with disabilities need } \\
\text { special facilities or infra-structure. } \\
\text { R2: In dealing with disabled } \\
\text { children, many teachers are } \\
\text { needed. }\end{array}$ \\
\hline Social & $\begin{array}{l}\text { R1: If a student has a learning } \\
\text { disability in an ordinary school, then } \\
\text { the student cannot socialize well } \\
\text { with the teacher and other students. }\end{array}$ & $\begin{array}{l}\text { R1: Children with disabilities will be } \\
\text { bullied. }\end{array}$ & $\begin{array}{l}\mathrm{R} 1 \text { : It is feared there will be } \\
\text { exiled. }\end{array}$ \\
\hline
\end{tabular}

International Journal of Instruction, January2019 • Vol.12, No.1 


\section{Cognitive Support}

There are parents who have a perception that inclusive education can develop disabled students' talents and abilities. It can also develop the creativity and ability of disabled students in order to develop. By being placed in one place will stimulate the way of thinking of children with disabilities.

\section{Behavioural Support}

When a disabled child interacts with a normal child of the same age, it will support him/her in obtaining his/her age-appropriate development. This will also add to his/her experience and make him/her feel no different from other children. It is expected that children with disabilities with normal children can share and learn to respect each other, respect and love.

\section{Facilities Support}

Inclusive education will help parents who have low economies to be able to send their children to school in general. School distance can be adjusted according to the location of his/her house. School fees can be cheaper.

\section{Social Support}

Inclusive education will help disabled students interact with peers so that their selfesteem increases. Besides this, socialization will make them accustomed to expressing feelings to others. This system applies the same position in education.

\section{Cognitive Refuse}

Response refuse can be seen from the statement of parents who said that children with disabilities cannot capture the lesson well, not quickly responsive in respondents like other normal children, and unequal ability, can hinder the learning process. Children with disabilities need special education such as extraordinary education. When a disabled child is schooled in a public school, it is feared to burden the child.

\section{Behavioural Refuse}

Public schools cannot maximize the potential for handicapped children because children with disabilities should get more special teaching than normal children. The public school environment will make disabled children ostracized, and ridiculed by their friends. They need a place, learning methods, and special teachers.

\section{Facilities Refuse}

General teachers cannot serve students with special needs individually so that special teachers are needed so that children with disabilities can develop. Facilities and infrastructure used in public schools have not been able to support the learning process for children with disability. They should get an education at an extraordinary school. 


\section{Social Refuse}

When a disabled child goes to school in the same place as a normal child, it is feared that he will experience difficulties in socializing with the teacher and his friends, In addition, disabled children will feel isolated from their environment.

\section{DISCUSSION}

The results from the analysis from interviews with parents produced several types of responses (table 4), namely discrimination on the perception of education; children have the right to education; parents did not understand inclusive education, and inclusive education helped the development of children with special needs.

In addition, the analysis results are classified into four perceptions, both those that support and those that reject the existence of inclusive education (table 5), namely cognitive, behavioral, facility and social. These results illustrate that there are differences of opinion among parents regarding inclusive education. It isconsidered that parents do not understand the purpose of implementing inclusive education so that some people think that it is dangerous.

The implications of this study expected that the relevant stakeholders should be able to socialize in advance about inclusive education before the system is implemented so parents understand the usefulness of inclusive education for the development of their children. This problem also occurs in various countries as implementing inclusive education without considering their needs (Hodkinson, 2010). Parents should be involved within the inclusion education process because successful education depends on an adult support (Leyser \& Kirk, 2011).

If parents have a good perception of inclusive education, it will help the successful implementation of inclusive education at schools. This is because the perception of parents will affect the perception of the child, especially in primary school children. The results of the study by Kalabula (2000) states that the perception of parents who have disabled children and parents who have normal children differ about inclusive education. Parents who have disabled children are very enthusiastic about inclusion education compared to parents who have normal children, so it is necessary to provide understanding to parents who have normal children about the goals in inclusive education.

Positive parental perception will cause any program to inclusive education to be able to run well because there will be parent involvement to give understanding to their child to petrify children with disabilities. The success of inclusive education is influenced by social communication and collaborative skills so that with normal students open to help will be able to support inclusive practices (Jones, 2005).

The limitation of this research is the use of a single data collection technique that causes the possibility of researcher subjectivity to occur. There are time and cost limitations that cause researchers to be unable to carry out other data collection techniques. 
Therefore, further research is expected to use other data collection techniques so that it can synchronize the findings of this study.

\section{CONCLUSION}

Inclusive education is an educational service that involves children with learning disabilities together with normal children in regular schools closest to their homes, which aim to improve the ability of children with disabilities in learning. In implementing inclusive education, the role of parents is needed. Parents' positive perception of inclusive education will help the successful implementation of inclusive education at schools because parents' perceptions will affect children's perceptions, especially in elementary school children. In addition, the role of stakeholders in socializing the goals of inclusive education must be prioritized before the inclusive education system is implemented.

\section{ACKNOWLEDGEMENTS}

The writers would like to express their gratitude to the Indonesian government, especially the Indonesian Directorate General of Higher Education (DIKTI), Indonesia Endowment Fund for Education (LPDP) in funding this research.

\section{REFERENCES}

Afolabi, O. E., Mukhopadhyay, S., \& Nenty, H. J. (2015). Linking Parents 'Role Belief for Involvement with Success of Inclusive education: Do Gender, Marital Status and Education Matters?. Educational Research Journal, 5(3), 36-55.

Armstrong, D. (1998). Changing faces, changing places: Policy routes to inclusion. In P. Clough (Ed.), Managing inclusive education: From policy to experience (pp. 31-47). London: Paul Chapman.

Avramidis, E., Bayliss, P., \& Burden, R. (2000). 'A Survey into Mainstream Teachers' Attitudes towards the Inclusion of Children with Special Educational Needs in the Ordinary School in One Local Education Authority.'. Educational Psychology, 20(2), 181-207.

Badan Pusat Statistik Provinsi Lampung. (2014). Indeks Pembangunan Manusia. Retrieved from https://lampung.bps.go.id/

Bazeley, P., \& Jackson, K. (Eds.). (2013). Qualitative data analysis with NVivo. London: Sage Publications Limited.

Blandul, V. C. (2010). International Approaches To Inclusion Of Children With Special Educational Needs In Mainstream Education. Problems of Education in the 21st Century, 21.

Dare, L., Nowicki, E. A., \& Felimban, H. (2017). Saudi Children's Thoughts on Inclusive Education. International Journal of Inclusive Education, 21(5), 532e543. 
Deng, M., \& Zhu, Z. (2007). The Chinese "Learning in a Regular Classroom" and Western Inclusive Education: A comparison and Exploration. Chinese Education \& Society, 40(4), 21-32.

DePauw, K. P., \& Doll-Tepper, G. (2000). Toward Progressive Inclusion and Acceptance: Myth or reality? The Inclusion Debate and Bandwagon Discourse. Adapted Physical Activity Quarterly; APAQ, 17(2), 135-143.

Direktorat Pembinaan Sekolah Luar Biasa. (2004). Pedoman Penyelenggaraan Pendidikan Inklusif (Buku Paket). Jakarta: Direktorat PSLB.

Fang, J. M. (2006). Inclusive Education and Teacher Education. [Educational Science edition]. Journal of East China Normal University, 24(3), 37-42, 49.

Hodkinson, A. (2010). Inclusive and Special Education within the English Education System: Historical perspectives, recent developments and future challenges. British Journal of Special Education, 37(2), 61-67.

Hunt, P., \& McDonnell, J. (2007). Inclusive education. In S. L. Odom, R. H. Horner, M. E. Snell, \& J. Blacher (Eds.), Handbook of developmental disabilities (pp. 269-291). New York: The Guilford Press.

Jones, P. (2005). Inclusion: Lessons from the Children. British Journal of Special Education, 32(2), 60-66.

Kalabula, M.D. (2000, July). Inclusive education in Africa: a myth or reality? A Zambian case study. Paper presented at the International Special Education Congress 2000. University of Manchester.

Lazarević, E., \& Kopas-Vukašinović, E. (2013). The Role and Place of Parents of Children with Disabilities in Inclusive Education in Serbia. International Journal about Parents in Education, 7(2).

Leyser, Y., \& Kirk, R. (2011). Parents' Perspectives on Inclusion and Schooling of Students with Angelman Syndrome: Suggestions for Educators. International Journal of Special Education, 26(2), 79-91.

Nilholm, C. (2006). Special Education, Inclusion and Democracy. European Journal of Special Needs Education, 21(4), 431-445.

Pérez Carreón, G., Drake, C., \& Calabrese Barton, A. (2005). The Importance of Presence: Immigrant Parent's School Engagement Experiences. American Educational Research Journal, 42(3), 465-498.

Qi, J., \& Ha, A. S. (2012). Inclusion in Physical Education: A review of Literature. International Journal of Disability Development and Education, 59(3), 257-281.

Reay, D. (2005). Mothers' involvement in their children's schooling: Social reproduction in action. In G. Crozier \& D. Reay, D (Eds.), Activating participation: Parents and teachers working towards partnership (pp. 23-38). UK: Trentham Books Ltd. 
Ring, E., \& Travers, J. (2005). Barriers to Inclusion: A Case Study of a Pupil with Severe Learning Difficulties in Ireland. European Journal of Special Needs Education, 20(1), 41-56.

Specht, J. A. (2013). Mental Health in Schools: Lessons Learned from Exclusion. Canadian Journal of School Psychology, 28(1), 43e55.

Starczewska, A., Hodkinson, A., \& Adams, G. (2012). Conceptions of Inclusion and Inclusive Education: A Critical Examination of the Perspectives and Practices of Teachers in Poland. Journal of Research in Special Educational Needs, 12(3), 162-169.

Tassoni, P. (2003). Supporting Special Needs: Understanding Inclusion in the Early Years, Oxford: Heinemann Educational Publishers, p. 12.

UNESCO. (1994). The Salamanca Statement and Framework for Action on Special Needs Education. Paris, France: United Nations Education, Scientific and Cultural Organization.

UNESCO. (2005). Guidelines for Inclusion: Ensuring Access to Education for All. Paris: United Nations Educational, Scientific and Cultural Organization.

Xu, Y., \& Filler, J. (2008). Facilitating Family Involvement and Support for Inclusive Education. School Community Journal, 18(2), 53.

Yin, R. K. (1994). Case Study Research: Design and Methods (Applied Social Research Methods, Vol. 5). Sage Publications, Beverly Hills, CA. Rick Rantz Leading urban institutions of higher education in the new millennium Leadership \& Organization Development Journal, 23(8), 2002.

Yu, L., Su, X., \& Liu, C. (2011). Issues of Teacher Education and Inclusion in China. Prospects, 41(3), 355-369.

Zigmond, N., Kloo, A., \& Volonino, V. (2009). What, Where, and How? Special Education in the Climate of Full Inclusion. Exceptionality, 17(4), 189-204. 